\title{
NON-FARM LIVELIHOOD DIVERSIFICATION: STRATEGIES AND CONSTRAINTS IN SELECTED RURAL AND PERI-URBAN COMMUNITIES, GHANA
}

\author{
Kofi Yeboah Asare ${ }^{\bowtie}$, Frederick Koomson ${ }^{2}$, Joseph Boateng Agyenim² \\ ${ }^{1}$ Local Government Service, Ghana, ${ }^{2}$ University of Cape Coast, Ghana
}

\begin{abstract}
Non-farm livelihood diversification is an important livelihood strategy for rural households in Sub-Saharan Africa. However, the available evidence suggests that these strategies have received less attention; therefore, the constraints rural people face in venturing into the non-farm sector also remain unaddressed. In order to understand the livelihood strategies and constraints in the sector, this paper used crosssectional survey data from 251 randomly sampled farmers from the Sunyani West District, Ghana. Focus Group Discussions were also conducted in order to collect qualitative data to support quantitative analysis. The data were analyzed using descriptive statistics: frequencies, percentages and cross tabulation. The study found that the non-farm sector was heterogeneous and highly gendered and involved several activities, with trading being the most prominent one. Gender disaggregation of non-farm activities has underlying cultural and social bases resulting in different production roles for males and females. Although farmers are predominantly engaged in farming as their major livelihood strategy, they also pursue non-farm livelihood activities due to push, rather than pull, factors. Inadequate access to credit and limited business opportunities were the major constraints impeding the development of the non-farm sector in the district. In order to propel rural development, policy makers and researchers should give attention to the development of the non-farm sector since it is an important source of income for many people. Apart from that, the study recommends that banking and micro-finance institutions design special credit programmes for rural people.
\end{abstract}

Keywords: non-farm, diversification, rural, strategies, constraints, Ghana

\section{INTRODUCTION}

Rural households and the economy of Sub-Saharan Africa are mostly seen as being dependent solely on agriculture (Senadza, 2012), with agriculture defined narrowly, i.e. livestock and crop production (Taruvinga et al., 2018). As a result, most rural development interventions aimed at reducing rural poverty and propelling growth have been centered around agriculture (Babatunde, 2008). Extant literature on rural livelihood suggests that agriculture has not been able to contribute significantly to rural development and poverty reduction in Sub-Saharan Africa, compared to Latin America and Asia (Winters et al., 2010).

Rural development literature posits that rural households make up their livelihood on the basis of complex strategies, contrary to the narrow claim that agricultural production is the sole source of rural household income (Kilic et al., 2009). Livelihood structures in rural areas in developing countries have been showing tremendous changes in the last few decades (Jan et al., 2012). It has been advanced that relatively few households in SubSaharan Africa earn their income from only one livelihood source, and use their endowments in just one livelihood portfolio (Senadza, 2012). Barrett et al. (2001) and Haggblade et al. (2007) concurred that households in Sub-Saharan Africa, especially of rural dwellers, earn their income from multiple livelihood strategies.

\footnotetext{
$\bowtie$ Kofi Yeboah Asare, Local Government Service, Ghana, e-mail: slimoder@yahoo.co.uk, https://orcid.org/0000-0003-1491-229X
} 
Non-farm diversification is receiving an increasing amount of attention in policy as an important livelihood strategy that can help reduce poverty in Sub-Saharan Africa (FAO, 1998; Winter et al., 2010; Ndhleve et al., 2013). While efforts to increase agricultural productivity are essential for the food security and poverty reduction campaign (Tobin, 2009), non-farm livelihood diversification has been put forward as an equally important strategy for addressing rural poverty (Ellis and Freeman, 2004; Mesele, 2016) as well as reducing the vulnerability of poor people to livelihood insecurities (Khatun and Roy, 2012; Katega and Lifuliro, 2014). In Sub-Saharan Africa, it is viewed as a remedy to agriculture's failure to provide sufficient livelihood for a large number of rural dwellers (Bryceson, 2002).

In Ghana, the adoption of non-farm activities has gained massive acceptance in both urban and rural areas due to the constraints faced by households engaged in farming, even though the latter continues to occupy an important place in the livelihood systems (Asmah, 2011). Available evidence suggests that more people are moving to the non-farm sector (Owusu et al., 2011; Dary and Kuunibe, 2012; GSS, 2014). Approximately 3.7 million households (44.3\%) operate non-farm enterprises in Ghana (GSS, 2014), and these enterprises are organized in line with gender roles (Ajani, 2012; Zakaria et al., 2015), making sex the main determinant of the type of non-farm enterprise to set up (GSS, 2017). Since rural agricultural activities often do not suffice for the entire household labour force, non-farm activities provide alternative sources of livelihood for the excess labour (Van Den Berg and Kumbi, 2006). That notwithstanding, the two activities are complementary as the income earned from non-farm activities is mostly invested in agriculture and vice versa (Davis et al., 2017).

In the Sunyani West District, the citizenry mainly depend on rain-fed farming for subsistence production and their livelihoods are vulnerable to climatic shocks, market volatility, growing prices of agricultural inputs, limited land and post-harvest losses (GSS, 2013), and the condition of farming as well as condition of farmers in the district has not improved either. Diversification into non-farm enterprises can, therefore, fulfil the risk management and survival function for these farmers, especially where a lack of sufficient formal employment is also prevalent (Ackah, 2013).
Despite the importance of non-farm strategies for rural and peri-urban households, much is not known about them and the constraints involved in their operation (Tasie et al., 2012). The lack of effective appreciation of the heterogeneity of rural assets and diverse livelihood activities pursued by rural people have been cited as some of the reasons for the fact that poverty is endemic in rural Ghana and Sub-Saharan Africa (De Janvry and Sadoulet, 2001). The emergence of climate change, rapid population growth and limited agricultural opportunities make it clear that non-farm diversification has become a norm (Davis et al., 2017). It is in view of these inadequacies that the study sought to examine non-farm livelihood diversification strategies adopted by the farmers in the Sunyani West district and the constraints that they are facing. Aside from the forgoing discussions that encapsulate the background to the study, the gaps and the objectives of the study, subsequent sections of the paper cover a review of literature, methodology and results as well as discussion of field data. The final section of the paper is devoted to conclusions and recommendations.

\section{REVIEW OF RELATED LITERATURE}

This section discusses related literature on non-farm strategies, the composition of non-farm economy, motives for non-farm diversification and the constraints thereof. The term non-farm activities refers to small, informal enterprises in rural non-farm economy (Dary and Kuunibe, 2012). Haggblade et al. (2010) defined rural non-farm activities as comprising of all non-agricultural activities, mining and quarrying, household and non-household manufacturing, processing, repairing, construction, trade, transport and other services taken up in villages and rural towns of up to 50,000 populations and enterprises varying in size, from household's own account enterprises all the way to factories. This includes all non-agricultural activities in rural areas, including on-farm (but non-agricultural) activities such as agribusiness, trade and retail, rural industrialization, construction, tourism and mining (Nagler and Naude, 2014). The non-farm sector might be adaptive (switching to trading possibly in response to a drought), coping, or be a survival strategy as a response to livelihood shock. Rural non-farm economy cannot be viewed as homogenous, but it is rather categorized by its heterogeneity, 
incorporating self-employment, micro, small, and medium-sized enterprises (MSMEs) (Tuyen, 2014).

Non-farm economy is composed of a highly heterogeneous collection of trading, agro-processing, manufacturing, commercial and service activities (Ifeanyi-Obi and Matthews-Njoku, 2014; Mbah and Igbokwe, 2015). Even within the same country, strong differences emerge regionally as a result of different natural resource endowments, labor supply, location, infrastructural investments and culture (Wiggins and Hazell, 2011). In Ethiopia and Malawi, Nagler (2015) observed that the non-farm sector is composed of: agricultural business, non-agricultural business, trade, sales, professional services, transportation, bars and restaurants. Dary and Kuunibe (2012) found that by tradition and social orientation, non-farm activities such as blacksmithing, wood carving, masonry, carpentry, butchery, photography, grinding mill operation, tractor operation and mechanical repair works were strictly performed by men. Conversely, pito brewing (local beer), sheabutter processing, food vending, pottery, and charcoal/fire wood production were found to be performed by women (Omirin and Okpara, 2018).

In general, households in rural Africa are motivated to diversify non-farm activities due to both 'push' and 'pull' factors (Barrett et al., 2001; Reardon et al., 2006). Ellis and Freeman (2004) explained the motives using the Asset-based and Insurance-based diversification theory. The Asset-based diversification theory explains that households with diversity of assets are pulled into the non-farm sector for investment opportunities. On the other hand, the Insurance-based diversification theory posits that households with limited opportunities in the agricultural sector are pushed into the non-farm sector as security against poor agricultural productivity. One key push factor is the high degree of risk in agriculture (Rijkers and Söderbom, 2013). In a study conducted in rural Ghana, Ackah (2013) found that in the presence of failures and imperfections in credit and insurance markets, risk-averse farmers diversified their income from agriculture in anticipation that crops may fail. Nagler and Naude (2014) also stated that households that have experienced food shortages due to crop failure are by 2.3 percent more likely to operate a non-farm enterprise. Therefore, risk aversion is an important reason behind some non-farm livelihood diversification in rural Africa.

Another important push factor that causes people to diversify in non-farm enterprises is inadequate access to land (Movahedi et al., 2012). It is clear in literature that people without access to land are mostly engaged in non-farm enterprises, while those with greater access to land seldom engage in the non-farm sector (Reardon et al., 2001). According to Fritzsch (2012), households with smaller landholdings depend too much on nonfarm activities in Indonesia. Households with adequate landholding are usually food secure and, as a result, participate to a lesser extent in non-farm activities, while households with limited or no landholding are mostly food insecure; therefore, non-farm activities are crucial to their survival (Rantšo, 2016).

Other push factors include; adverse weather conditions (floods, drought), response to diminishing factor returns, fragmented land holdings, reaction to crisis, seasonality and high input cost (Babatunde and Qaim, 2010; Haggblade et al., 2010). The push factors have also been described as Distress-Push diversification (Reardon et al., 2001), Involuntary diversification (Freese, 2010) and/or Survival-Led diversification (Atamanov and Berg, 2012). Since most people in rural Africa are poor and prone to these factors, they diversify to the non-farm sector to satisfy their basic needs.

The second set of motives for non-farm livelihood diversification is called pull-factors. Individuals may diversify in rural non-farm activities because of their desire to make use of business opportunities, in response to demand in rural areas (Freese, 2010). The demandpull factors are also described as voluntary diversification (Freese, 2010) or opportunity-led (Atamanov and Berg, 2012). Pull factors represent opportunities for livelihood improvements in the non-farm sector, which attract some individuals to participate in non-farm economy. This may be fueled by strategic complementarities between activities such as crop and livestock integration, specialization, comparative advantage accorded by superior technologies, skills or endowments (Ackah, 2013).

Household factors, as well as individual characteristics have also been identified as vital determinants of pulling individuals to diversify in rural non-farm enterprises (Nagler, 2015). These factors typically include sex, age, education, marital status, financial assets, household composition and the size of the household itself (Bhaumik et al., 2011). Among these factors, education is found to be relatively more important in terms of accessing non-farm wage employment (Beyene, 2008; Malek and Usami, 2009). In China, record keeping, 
management and literacy are required before opening and operating a non-farm business (Liu, 2012).

Another common pull factor is the availability of infrastructure such as utilities, good quality roads, market and proximity to urban centers (Abdul and Usami, 2009; Roepstorff and Wiggens, 2011). Inadequate access to infrastructural services, such as electricity and good quality roads are major constraints to non-farm diversification (Isgut, 2004). Gibson and Olivia (2010) state that in Indonesia people who diversify in the non-farm sector tend to live in communities where a high number of households have electricity. Consequently, the availability of transport, electricity, ICT and water is an important infrastructural factor that attracts many people to diversify livelihoods in non-farm enterprises (Rantšo, 2016).

\section{Constraints to non-farm livelihood diversification}

Despite the potential of the rural non-farm sector to accelerate growth and speed up poverty alleviation in Sub-Saharan Africa, it is facing several constraints in its day-to-day operations. The constraints to the non-farm sector include: poor or costly access to credits, obsolete production technologies, low level of technical and managerial know-how, inadequate knowledge of record keeping, high levels of competition among enterprises, inadequate opportunities, poor infrastructure and unfavorable macroeconomic conditions (Abor and Quartey, 2010; Bowen et al., 2009; Oppong et al., 2014). Additionally, SMEs in Africa are also limited by input constraints, undeveloped market channels and international market competition (Okpara, 2011).

In their study in Ghana and South Africa, Abor and Quartey (2010) observed that access to credits is a major problem frequently faced by non-farm enterprises. Inadequate access to institutional credits is a deterrent for non-farm livelihood diversification in many developing countries. In the absence of credit support from institutional agencies, the resource poor households are not able to invest in lucrative non-farm enterprises (Khatun and Roy, 2012). Ntiamoah et al. (2016) also observed that, notwithstanding the recognition of the role of small enterprises in the development process in many developing countries, their development is always constrained by the limited availability of financial resources to satisfy a variety of operational and investment needs. As a result, many operate with elementary equipment which results in low productivity.
Another constraint to non-farm livelihood diversification is poor asset base (Scoones, 2009). According to Khatun and Roy (2012), possession of even a small asset enables households to take up opportunities in the non-farm sector, particularly in the self-employment sector. For example, ownership of a sewing machine may induce a person to start their own tailoring business. Similarly, being an owner of a bicycle may help a worker with going to the nearby town to seek non-agricultural employment. Most landless and small farmers do not have assets, which constitutes a barrier to nonfarm livelihood diversification.

With the opening of national markets to all types of producers under globalization, non-farm enterprises find it difficult to effectively compete with large multinational companies due to costs, pricing, quality, market reach and appeal. According to Weatherspoon and Reardon (2003), trade liberalisation is an obstacle to viable rural non-farm livelihood diversification since the local enterprises are out-competed by giant multinational companies. Kristiansen (2004) also argues that the lack of knowledge of and access to business information makes small-scale businesses in developing countries vulnerable to liberalisation and increased global competition.

In addition to the above, due to low specialization, rural non-farm enterprises are not innovative. In the capitalist world, competition is very important and, therefore, companies must adopt new technologies to accumulate more profits in order to stay in business (Saith, 2001). However, this is not the case with rural non-farm enterprises where household-based techniques and forms of production are used (Saith, 2001). According to Kristiansen (2004), small-scale African entrepreneurs copy the brands of other imported products instead of being innovative, which presents them with stiff competition.

\section{METHODOLOGY}

The paper adopted the mix research methodology by employing quantitative and qualitative approaches. The cross sectional survey design was adopted to address the objectives of the study with respect to the constraints of livelihood diversification of farmers in the Sunyani West District of the Bono Region, Ghana. The population included in the study was made up of the farmers of the Sunyani West District. The target population was composed of farmers who have been registered in the 
Department of Agriculture of the District Assembly (SWDA, 2017). It was made up of farmers from three agriculture operational zones (Nsoatre, Odumasi and Chiraa).

A combination of purposive, proportional, and simple random sampling procedures was applied to select specific study communities and sampled farmers. First, the district was stratified into three areas based on the operational zones of the Department of Agriculture. Second, one rural and peri-urban community were purposively selected from each of the zones. The selection criterion depended on the communities with the highest numbers of persons registered in the Department of Agriculture. The six sampled communities were Odumasi No. 1, Kwatri, Dumasua, Mantukwa, Chiraa-Asuakwaa and Kobedi. The total number of registered farmers in the six selected communities was 770 . The Krejcie and Morgan's (1970) table was used to determine the sample size of 260 , out of a population of 770 , for the study. A proportion was given to each of the three zones depending on the population of farmers in the given sample frame. The addresses and the registration numbers of the farmers from the six selected communities were entered into Microsoft Excel after which the tool for selecting random numbers was used to select the final sample based on the determined proportions. A total of 260 farmers were selected from the six communities, as presented in Table 1 . In addition to the 260 farmers, officers of the District Assembly, representatives of the FBOs, and persons operating non-farm enterprises were divided into two focus discussion groups.

Data for the study were collected from both primary and secondary sources. Primary data were collected from the sampled farmers using a structured interview schedule and a Focus Group Discussion (FGD) guide.

Table 1. Distribution of sample by community and zone

\begin{tabular}{lcrcc}
\hline \multirow{2}{*}{ Zone } & $\begin{array}{c}\text { Total number } \\
\text { of registered } \\
\text { farmers }\end{array}$ & \multicolumn{2}{c}{ Sample per location } & \\
\cline { 3 - 4 } & 277 & 34 & 60 & 94 \\
\hline Nsoatre & 276 & 27 & 66 & 93 \\
Odumasi & 217 & 40 & 33 & 73 \\
Chiraa & 217 & peri-urban & \\
Total & 770 & 140 & 120 & 260 \\
\hline
\end{tabular}

Source: field survey, 2017.
The interview schedule was chosen over the questionnaire because the study was conducted in a rural and peri-urban setting where about 20 percent of people are illiterate (GSS, 2014). This approach prevented possible misunderstanding or misinterpretation of the items in the instruments, which could have led to erroneous conclusions. The secondary data came from the reports of the Department of Agriculture, Annual Action Plan and Composite Budget of the District Assembly. Data from the field were processed and analyzed using the Statistical Product and Service Solutions (SPSS) software version 21. Quantitative data were analyzed using both descriptive and inferential statistics. A narrative type of analysis was also performed to present the qualitative data to support the quantitative analysis.

\section{RESULTS AND DISCUSSION}

This section presents the results and discussion of the field data based on the objectives of the study. The presentation begins with the description of the background information of respondents, followed by the non-farm livelihood diversification strategies of farmers. The final part of this section discusses constraints in livelihood diversification faced by farmers. 251 out of the 260 sampled respondents agreed to participate in the study. The discussion of the field data is, therefore, based on a response rate of 96.5 percent.

The examined background variables were sex, age and educational level as well as the primary occupation of the respondents. These variables to a greater extent determine the likelihood of a farmer to diversify. With respect to sex, 58.6 percent of the 251 respondents were males and the rest were females. The results further showed that a greater proportion $(98.0 \%)$ of household heads were males. The age distribution of the respondents showed that the youngest farmer was 20 , and the oldest -84 . The median age of the respondents was 42 years (mean $=45$ years, skewness $=.563$ ) with a quartile deviation of 18 years. It became evident that some $(19.9 \%)$ of the farmers had no formal education, compared to the majority (55.4\%) of the respondents who were educated up to the basic level (Junior Secondary School/Middle school).

As part of the analysis, in order to identify nonfarm livelihood activities pertaining to the study area, the study examined the primary occupation of the respondents. The majority (53.4\%) of the 236 farmers 
Asare, K. Y., Koomson, F., Agyenim, J. B. (2021). Non-farm livelihood diversification: strategies and constraints in selected rural and peri-urban communities, Ghana. J. Agribus. Rural Dev., 1(59), 5-15. http://dx.doi.org/10.17306/J.JARD.2021.01360

who responded to this item considered farming as their primary occupation. The rest (46.6\%) of the respondents considered non-farm livelihood activities as their main occupation, and farming as their secondary occupation. However, those who considered non-farm livelihood activities as their primary occupation mentioned that they changed their occupation due to constraints in the farming sector. From the results it can be inferred that farming is the primary occupation for the majority of the respondents even though most of them have diversified into non-farm livelihood activities as postulated by the push-factors for diversification (Ellis and Freeman, 2004), contrary to the findings of Omirin and Okpara (2018) according to which rural people in Ido local government area, Nigeria, diversified due to pull-factors. The findings further confirm (Babatunde, 2008; Senadza, 2012) that most farmers are not confined to farming activities but rather combine farming with non-farm livelihood activities (Ekong, 2010).

The study further disaggregated the primary occupation by sex, due to the fact that the literature suggests that there are differences differences in the primary occupation of males and females (Dary and Kuunibe, 2012). It was found that farming was the primary occupation for a greater proportion of male respondents $(61.2 \%)$ than female respondents $(43.1 \%)$. The difference in the primary occupation of males and females was found to be significant. The finding is consistent with the findings of Ajani (2012) and Zakaria et al. (2015), according to which females prefer non-farm livelihood activities to farming, while males significantly engage in crop production. It may stem from the fact that a greater proportion of farmland is owned by men as well as their position as household heads, which enables them to be engaged in farming to a greater extent than women. It could also stem from the fact that women prefer household enterprises to farming, to have time to honor their reproductive and community service roles.

\section{Non-farm livelihood diversification strategies adopted by farmers}

This section of the study describes the non-farm livelihood diversification strategies adopted by the farmers in the study area. Farmers participate in different types of non-farm livelihood activities due to various reasons stemming from either push or pull factors. The types of non-farm livelihood activities that farmers engage in vary from one area to another, depending largely on the
Table 2. Distribution of non-farm livelihood sector by sex

\begin{tabular}{lrrrrrr}
\hline & \multicolumn{4}{c}{ Sex } & \multicolumn{2}{c}{ Total } \\
\cline { 2 - 5 } $\begin{array}{l}\text { Non-farm live- } \\
\text { lihood sector }\end{array}$ & \multicolumn{2}{c}{ male } & \multicolumn{2}{c}{ female } & & $\begin{array}{r}\text { \% of } \\
\text { freq. }\end{array}$ \\
\cline { 2 - 5 } & $\begin{array}{r}\text { \% of } \\
\text { male }\end{array}$ & freq. & $\begin{array}{r}\text { \% of } \\
\text { female }\end{array}$ & & \\
\hline Commerce & 67 & 77.9 & 29 & 27.4 & 96 & 50.0 \\
Manufacturing & 3 & 3.5 & 5 & 4.7 & 8 & 4.2 \\
Service & 16 & 18.6 & 72 & 67.9 & 88 & 45.8 \\
Total & 86 & 100.0 & 106 & 100.0 & 192 & 100.0 \\
\hline
\end{tabular}

Source: field survey, 2017.

type of resources found in the area. A total of 192 farmers provided responses on their non-farm livelihood activities. Various non-farm activities were categorized into commerce, manufacturing and service. The study further distributed the activities according to sex (Table 2) as literature posits that non-farm activities are gendered.

Evidence from Table 2 shows that a half $(50 \%)$ of the respondents diversified into the commerce sector, while most (45.8\%) were in the service sector. Only 4.2 percent were in manufacturing. This distribution may be attributed to the fact that it is easy to enter commerce and service sectors because they require low start-up capitals, unlike manufacturing which requires initial overhead cost in the form of equipment and machinery. A Chi-Square of homogeneity was used to determines the difference in sex with respect to a non-farm sector of choice. The test showed a significant difference in the preference of non-farm sector for males and females. While males $(77.9 \%)$ were generally involved in commerce, females $(67.9 \%)$ largely diversified into the service sector, as presented the table.

The study further disaggregated sectors by identifying specific activities that the respondents were engaged in, the details of which are presented in Table 3. Descriptive statistics indicate that most $(36.5 \%)$ of the farmers diversified into trading activities, with the majority $(57.0 \%)$ of the traders being females. Food vending remained a female activity, while the lotto business was the preserve of males. These findings are rooted in culture as it is the duty of women to work for their households. This supports earlier findings of Ifeanyi-Obi and Matthews-Njoku (2014) and Mbah and Igbokwe (2015), 
Asare, K. Y., Koomson, F., Agyenim, J. B. (2021). Non-farm livelihood diversification: strategies and constraints in selected rural and peri-urban communities, Ghana. J. Agribus. Rural Dev., 1(59), 5-15. http://dx.doi.org/10.17306/J.JARD.2021.01360

Table 3. Distribution of non-farm livelihood activities by sex

\begin{tabular}{|c|c|c|c|}
\hline $\begin{array}{c}\text { Non-farm livelihood } \\
\text { activities }\end{array}$ & $\begin{array}{l}\text { Female } \\
\text { No }(\%)\end{array}$ & $\begin{array}{c}\text { Male } \\
\text { No }(\%)\end{array}$ & $\begin{array}{c}\text { Total } \\
\text { No }(\%)\end{array}$ \\
\hline \multicolumn{4}{|c|}{ Commerce sector } \\
\hline Trading & $49(57.0)$ & $21(19.8)$ & $70(36.5)$ \\
\hline Food vending & $16(18.6)$ & $0(0.0)$ & $16(8.3)$ \\
\hline Lotto & $0(0.0)$ & $3(2.8)$ & $3(1.6)$ \\
\hline Firewood/ Charcoal & $1(1.2)$ & $2(1.9)$ & $3(1.6)$ \\
\hline Drinking spot & $1(1.2)$ & $3(2.8)$ & $4(2.1)$ \\
\hline \multicolumn{4}{|l|}{ Manufacturing sector } \\
\hline $\begin{array}{l}\text { Processing of farm } \\
\text { produce }\end{array}$ & $0(0.0)$ & $2(1.9)$ & $2(1.0)$ \\
\hline Soap making & $2(2.3)$ & $0(0.0)$ & $2(1.0)$ \\
\hline Alcohol brewing & $1(1.2)$ & $0(0.0)$ & $1(0.5)$ \\
\hline Craft work & $0(0.0)$ & $3(2.8)$ & $3(1.6)$ \\
\hline \multicolumn{4}{|c|}{ Service sector } \\
\hline Masonry & $0(0.0)$ & $15(14.2)$ & $15(7.8)$ \\
\hline Carpentry & $0(0.0)$ & $9(8.5)$ & $9(4.7)$ \\
\hline Driving/Transport & $0(0.0)$ & $19(17.9)$ & $19(9.9)$ \\
\hline Dressmaking & $10(11.6)$ & $6(5.7)$ & $16(8.3)$ \\
\hline Electrician & $0(0.0)$ & $3(2.8)$ & $3(1.6)$ \\
\hline Vulcanizing & $0(0.0)$ & $2(1.9)$ & $2(1.0)$ \\
\hline Milling & $0(0.0)$ & $3(2.8)$ & $3(1.6)$ \\
\hline Hairdressing/barber & $6(7.0)$ & $1(0.9)$ & $7(3.6)$ \\
\hline Metal fabrication & $0(0.0)$ & $6(5.7)$ & $6(3.1)$ \\
\hline Bicycle/motor repair & $0(0.0)$ & $7(6.6)$ & $7(3.6)$ \\
\hline Other & $0(0.0)$ & $1(0.9)$ & $1(0.5)$ \\
\hline Total & $86(100.0)$ & $106(100.0)$ & $192(100.0)$ \\
\hline
\end{tabular}

Source: field survey, 2017.

according to which farming and trading were the major livelihood activities pursued by rural dwellers. This is partly attributed to the lower entry barriers, namely skills and start-up capital required for these activities.

With respect to manufacturing, none of the males diversified into soap making and alcohol, but focused on the processing of farm produce and craftwork as compared to the females who were involved in soap making and alcohol brewing. Like commerce and manufacturing, the service sector was also highly gendered with none of the females involved in masonry, carpentry, transport, electrical works, vulcanizing, milling, metal fabrication and motor repair activities (Table $3)$. These findings are consistent with the findings of Dary and Kuunibe (2012). According to these authors, tradition and social orientation may prevent some individuals from engaging in certain non-farm livelihood activities because of their sex. This implies that the sex of rural farmers prevented them from diversifying into certain non-farm activities. For instance, Zakaria et al. (2015) found that there were significant differences in gender participation in non-farm employment and nonfarm wage labour in Northern Ghana. At the FGD it transpired that this trend may not change anytime soon as males and females prefer to operate in their culturally and socially acceptable activities.

\section{Constraints to non-farm livelihood diversification}

This section of the paper discusses constraints related to the diversification of non-farm livelihood activities. In view of the fact that rural non-farm activities are heterogeneous by nature, their constraints also have differing characteristics. The constraints to non-farm self-employed livelihood diversification are the main focus of this section. The study focused on the major constraints identified by the interview schedule respondents and ones found at the FGDs.

To begin with, respondents were asked if they were constrained from diversifying into non-farm activities. Out of the 240 farmers who responded to this item, 95.6 percent were constrained from running a non-farm enterprise. As presented in Table 4, according to approx. 42 percent of the 361 multiple responses, the constraints were related to credit. A similar concern was raised by the participants of the FGD. The respondents who mentioned credit as a constraint stated that it stemmed from the absence of collateral/guarantee, high interest rates, unwillingness of creditors, unfavorable repayment schedule and the fear of the consequences of default.

The implication is that most farmers will find it difficult to diversify their livelihood to improve their standards of living. This finding is supported by the Ghana Living Standard Survey (GLSS-7) (2017), according to which the main source of starting a non-farm enterprise are household savings $(70.7 \%)$, followed by loans from friends and relatives $(16.9 \%)$. This development will 
Table 4. Constraints to non-farm livelihood diversification

\begin{tabular}{lcc}
\hline \multicolumn{1}{c}{ Aims } & Frequency & Percent \\
\hline Credit & 151 & 41.8 \\
Inadequate opportunities & 63 & 17.5 \\
Lack of training & 39 & 10.8 \\
Poor asset base & 32 & 8.8 \\
Fear of risk & 30 & 8.3 \\
Poor infrastructure & 19 & 5.3 \\
High rate impost & 16 & 4.4 \\
Inadequate time & 6 & 1.7 \\
Poor electricity supply & 4 & 1.1 \\
Influence of spouse & 1 & 0.3 \\
Total & $361^{*}$ & 100 \\
\hline
\end{tabular}

*Multiple responses exist.

Source: field survey, 2017.

crowd many farmers out of starting a non-farm activity as most households produce from hand to mouth, with little or no savings. The GLSS-7 (2017) further shows that about 90 percent of those involved in manufacturing, 95.9 percent of those involved in industry and about 91 percent of service sector entrepreneurs did not use credit. This finding is consistent with Abor and Quartey (2010) as well as Zakaria et al. (2015), according to which credit constitutes a major constraint to non-farm livelihood diversification. The constraints with respect to credit for start-up and re-capitalisation of non-farm activities were also consistent with those observed by Katega and Lifuliro (2014) in Tanzania and by Mesele (2016) in Ethiopia. These authors also found that credit, low opportunities, skill deficiency and inadequate capital are constraints to non-farm activities. Similarly, Ntiamoah et al. (2016) observed that inadequate access to financial resources slows down the development of the non-farm sector.

The second highly cited constraint was inadequate business opportunities (17.5\%). Some participants of the FGD also reiterate that there are fewer opportunities in the non-farm livelihood sector in the district. It came up strongly that sales were very low and credit sales were common, which also always reduced the volume of cash in hand to turn businesses around. Respondents from rural communities specifically mentioned absence of market facilities as a major contributing factor to limited business opportunities in their communities. This could be linked to the low income levels of most people in rural areas as found by Zakaria et al. (2015) and the GLSS-7 (2017). According to the GLSS-7 (2017), rural dwellers spend most of their earnings $(32.8 \%)$ on fuel and lubricants, which reduces their disposable income that can be spent on other commodities. Some participants also indicated low level of patronage from the citizenry as a result of competition as most farmers are diversifying into similar activities because of the high risk associated with farming in the study area.

Also, about 11 percent of responses in the survey referred to a lack of training. The lack of training was also mentioned at the FGD sessions as a major constraint to non-farm livelihood diversification. Some participants mentioned that before any farmer starts a certain nonfarm livelihood activity, he/she should have enough technical training and be provided with basic business advisory services with regard to the chosen activity. Respondents stated that the only training they were receiving was agriculture-related training conducted by the Agriculture Extension Officers, directly related to farm activities rather than non-farm activities. Training geared towards the non-farm sector was virtually not available to them. The finding was confirmed by the 2015 composite budget of the District Assembly, which highlighted that inadequate capacity to design programmes for Micro and Small Enterprises (MSEs) was a major challenge faced by the district (SWDA, 2015). Poor skills of people working in the non-farm sector were also reiterated by the GLSS-7 (2017), according to which about 36 percent of those engaged in non-farm activities were unskilled.

Aside from credit, inadequate opportunities and the lack of training, 8.8 percent of the responses referred to poor asset base. This is a general problem for the majority of people in the non-farm sector. According to, for example, the GLSS-7 (2017) only 11.5 percent of the total assets of non-farm operators are in the form of machinery, equipment and tools.

Another constraint of non-farm enterprises, which was indicated by 8.3 percent of the respondents, was the fear to take a risk. According to a section of participants in the FGDs, the absence of institutional support sometimes limited the ability of farmers to pursue businesses. Most of the participants of the FGDs feared that they would fail while investing in non-farm activities 
requiring relatively higher initial start-up capital. This has implications for diversification as the perceived fear of failure deterrs farmers from exploring opportunities in the non-farm sector. This finding is consistent with that of Roy and Khatun and Roy (2013), who explained that the choice of livelihood activities by rural people was greatly influenced by the fear of failure. Details of the other, relatively less pressing constraints are presented in Table 4 .

\section{CONCLUSIONS AND RECOMMENDATIONS}

Non-farm activities in the study area were heterogeneous and involved small sized self-employment. Most importantly, farming and trading were the most predominant livelihood strategies pursued by farmers. Besides, the primary occupation of the respondents was farming, but the sector was risky, which pushed farmers to adapt non-farm livelihood activities to cushion the uncertainties in the agricultural sector. Non-farm livelihood activities are highly gendered, with female farmers dominating in trade, food vending and soap making, and male farmers involved in processing, metal fabrication, milling and transport. The gender disaggregation of these non-farm activities stems from cultural and social factors, resulting in different production roles of males and females. Prominent constraints included: inadequate credit, limited business opportunities, poor asset base and a lack of training. Other constraints were: poor infrastructure and fear of failure.

It is therefore recommended that due to the heterogeneity of the non-farm sector, farmers should be provided with business advice services that would enable them to determine which activities were viable in the district. Apart from that, since agriculture is no longer the only livelihood source for rural and peri-urban farmers in the Sunyani West District, the government must support the growing informal sector. This support may be provided by allocating more budgets to rural areas to initiate productive economic activities. It is also recommended that any alternative livelihood programmes for farmers must take into consideration the prevailing cultural and social norms that as a glass ceiling that discourages males and females from pursuing certain livelihood activities. Also, rural financing must be developed and improved. Rural banks and microfinance institutions must be encouraged to establish branches in the rural and agriculture communities so as to make financing of non-farm projects much easier. This will help the people obtain the needed credits for investment in non-farm activities to improve their income levels and their consumption.

\section{REFERENCES}

Abdul, M.M., Usami, K. (2009). Determinants of non-farm income diversification in developed villages of Bangladesh. Am. J. Econ. Bus. Econ., 1(2), 141-149.

Abor, J., Quartey, P. (2010). Issues in SMEs Development in Ghana and South Africa. Int. Res. J. Fin. Econ., 39(6), 215-228.

Ackah, C. (2013). Non-farm employment and Income in Rural Ghana. J. Int. Dev., 25, 325-339.

Ajani, E.N. (2012). Occupational diversification among rural women in Anambra State, Nigeria. Doctoral dissertation, University of Nigeria, Nsukka. Retrieved from: http:// www.academicjournals.org/journal/JAERD/article-fulltext pdf/0761F4842718

Asmah, E.E. (2011). Rural livelihood diversification and agricultural household welfare in Ghana. J. Dev. Agric. Econ., 3(7), 325-334.

Atamanov, A., Berg, M. (2012). Participation and returns in rural non-farm activities: evidence from the Kyrgyz Republic. Agric. Econ., 43(4), 459-471.

Babatunde, R.O. (2008). Income portfolios in rural Nigeria: Composition and determinants. Trends Agric. Econ, 1, 35-41.

Babatunde, R.O., Qaim, M. (2010). Impact of off-farm income on food security and nutrition in Nigeria. Food Polic., 35(4), 303-311.

Barrett, C.B., Reardon, T., Webb, P. (2001). Non-farm income diversification and household livelihood strategies in rural Africa: concepts, dynamics, and policy implications. Food Polic., 26(4), 315-331.

Beyene, A.D. (2008). Determinants of off-farm participation decision of farm households in Ethiopia. Agrekon, 47(1), 140-161.

Bhaumik, S.K., Dimova, R., Nugent, J.B. (2011). Off-farm labor supply and labor markets in rapidly changing circumstances: Bulgaria during transition. Econ. Syst., 35(3), 378-389.

Bowen, M., Morara, M., Mureithi, S. (2009). Mnagement of Business Challenges among Small and Micro Enterprises in Nairobi-Kenya. KCA J. Bus. Manag., 2(1), 16-31.

Bryceson, D.F. (2002). Multiplex livelihood in rural Africa: recasting the terms and conditions of gainful employment. J. Modern Afr. Stud., 40(1), 1-28.

Dary, S.K., Kuunibe , N. (2012). Participation in Rural NonFarm Economic Activities in Ghana. Am. Int. J. Cont. Res., 2(8), 154-161. 
Davis, B., Di Giuseppe, S., Zezza, A. (2017). Are African households (not) leaving agriculture? Patterns of households' income sources in rural Sub-Saharan Africa. Food Polic., 67, 153-174.

de Janvry, A., Sadoulet, E. (2001). Investing in rural development is good business. Development of Rural Economies. Washington, DC: Inter-American Development Bank.

Ekong, E. (2010). Introduction to Rural Sociology (3rd ed.). Uyo, Nigeria: Dove Educational Publishers.

Ellis, F., Allison, E.H (2004). Livelihood diversification and natural resource access (ODG Working Paper No.9). Rome, Italy: FAO.

Ellis, F., Freeman, H.A. (Eds.). (2004). Rural livelihoods and poverty reduction policies. Oxon, UK: Routledge.

FAO (1998). The State of Food and Agriculture: Rural NonFarm Income in Developing Countries. Rome: Food and Agriculture Organization.

Freese, A. (2010). An Analysis of Rural Non-Farm Sector Participation and Income:The Case of Burkina Faso. Gottingen: George-August University of Gottingen.

Fritzsch, J. (2012). Is non-farm income diversification a feasible option for small-scale farmers? An assessment using a composite fuzzy indicator. Post-Comm. Econ., 24(3), 403-417.

GSS (Ghana Statistical Service) (2013). 2010 Population \& Housing Census National Analytical Report. Accra, Ghana: Ghana Statistical Service.

GSS (Ghana Statistical Service) (2014). Ghana Living Standards Survey report of the Seventh round. Accra, Ghana: Ghana Statistical Service.

GSS (Ghana Statistical Service) (2014). Ghana Living Standards Survey report of the Sixth round. Accra, Ghana: Ghana Statistical Service.

GSS (Ghana Statistical Service) (2017). Ghana Living Standards Survey report of the seventh round. Accra, Ghana: Ghana Statistical Service.

Gibson, J., Olivia, S. (2010). The effect of infrastructure access and quality on non-farm enterprises in rural Indonesia. World Dev., 38(5), 717-726.

Haggblade, S., Hazell, P.B., Reardon, T. (2007). Transforming the rural nonfarm economy: Opportunities and threats in the developing world. Baltimore: John Hopkins Press.

Haggblade, S., Hazell, P., Reardon, T. (2010). The rural nonfarm economy: Prospects for growth and poverty reduction. World Dev., 38(10), 1429-1441.

Ifeanyi-Obi, C.C., Matthews-Njoku, E.C. (2014). Socioeconomic factors affecting choice of livelihood activities among rural dwellers in Southeast Nigeria. IOSR J. Agric. Vet. Sci., 7(4), 52-56.

Isgut, A.E. (2004). Non-farm Income and Employment in Rural Honduras:Assessing the Role of Locational factors. J. Dev. Stud., 40(3), 59-86.
Jan, I., Khattak, M.K., Khan, M.A., Hayat, S., Rahim, T. (2012). Factors affecting rural livelihood choices in Northwest Pakistan. Sarhad J. Agric., 28(4), 681-688.

Katega, I.B., Lifuliro, C.S. (2014). Rural non-farm activities and poverty alleviation in Tanzania: A case study of two villages in Chamwino and Bahi districts of Dodoma region (REPOA Research Report No. 14/7). Dar es Salaam, Tanzania: Repoa. Retrieved from: http://www.repoa.or.tz/ documents/REPOA_RR_14_7.pdf

Khatun, D., Roy, B. C. (2012). Rural livelihood diversification in West Bengal: determinants and constraints. Agric. Econ. Res. Rev., 25(1), 115-124.

Kilic, T., Carletto, C., Miluka, J., Savastano, S. (2009). Rural non-farm income and its impact on agriculture: evidence from Albania. Agric. Econ., 40(2), 139-160.

Krejcie, R.V., Morgan, D.W. (1970). Table for determining sample size from a given population. Educ. Psychol. Meas., 30(3), 607-610.

Kristiansen, S. (2004). Liberalisation, information and innovation: cottage garment industries in Tanzania. Eur. J. Dev. Res., 16(2), 375-395.

Liu, J. (2012). On the Rural Economy of China: How do Rural-Urban Migration and Rural Non-Farm Business Affect Each Other. Am. Int. J. Cont. Res., 2(4), 30-38.

Malek, M.A., Usami, K. (2009). Determinants of non-farm income diversification in developed villages of Bangladesh. Am. J. Econ. Bus. Adm., 1(2), 141.

Mbah, E.N., Igbokwe, E.M. (2015). Rural Non-Farm Enterprises for Empowerment of Women in Anambra State, Nigeria. Scientia, 11(1), 42-52.

Mesele, B.T. (2016). Rural Non-farm livelihood diversification among farming households in Saharti Samre Woreda, Southeastern Tigray.Doctoral dissertation, Addis Ababa University. Retrieved from http://www.etd.aau.edu.et/ bitstream/123456789/10048/1/2.Brhanu\%20Tsegay\%20 Final\%20E.pdf

Movahedi, R., Fathi, H., Latifi, S. (2012). The Effects of NonFarm Business in Rural Sustainable Development: A Case Study in Sanandaj's Rural Areas, Kurdistan. Int. J. Agric. Manag. Dev., 2(2), 113-120.

Nagler, P. (2015). Occupational choice in the developing world. Doctoral dissertation, Maastricht University). Retrieved from https://www.merit.unu.edu/training/theses/ paula.pdf

Nagler, P., Naude, W. (2014). Non-farm entrepreneurship in rural Africa: patterns and determinants (IZA Discussion Paper no. 8008). Bonn, Germany: Institute for the Study of Labour.

Ndhleve, S., Musemwa, L., Zhou, L. (2013). How severe hunger is amongst rural households of the Eastern Cape Province of South Africa. J. Econ. Sust. Dev, 4(3), 221-227. 
Asare, K. Y., Koomson, F., Agyenim, J. B. (2021). Non-farm livelihood diversification: strategies and constraints in selected rural and peri-urban communities, Ghana. J. Agribus. Rural Dev., 1(59), 5-15. http://dx.doi.org/10.17306/J.JARD.2021.01360

Ntiamoah, E.B., Li, D., Kwamega, M. (2016). Impact of Government and Other Institution's support on Performance of Small and Medium Enterprises in Agribusiness Sector in Ghana. Am. J. Ind. Bus. Manag., 6(5), 558.

Okpara, J.O. (2011). Special issue on small business development and poverty alleviation in Africa. Manag. Res. Rev., $34(2)$.

Omirin, O.J., Okpara, C. (2018). Off-farm activities as income strategies among rural women in Ido Local Government Area, Ibadan, Nigeria. Afr. J. Psychol. Stud. Soc. Iss., 21(2), 224-239.

Oppong, M., Owiredu, A., Churchill, R.Q. (2014). Micro and Small Enterprise Development in Ghana. Eur. J. Account Audit. Fin. Res., 2(6), 84-97.

Owusu, V., Abdulai, A., Abdul-Rahman, S. (2011). Non-farm work and food security among farm households in Northern Ghana. Food Pol., 36(2), 108-118.

Rantšo, T.A. (2016). The role of the non-farm sector in rural development in Lesotho. J. Modern Afr. Stud., 54(02), 317-338

Reardon, T., Berdegué, J., Escobar, G. (2001). Rural non-farm employment and incomes in Latin America: overview and policy implications. World Dev., 29(3), 395-409.

Reardon, T., Berdegué, J., Barrett, C., Stamoulis, K. (2006). Household income diversification into rural non-farm activities. Baltimore: John Hopkins University Press.

Rijkers, B., Söderbom, M. (2013). The effects of risk and shocks on non-farm enterprise development in rural Ethiopia. World Dev., 45, 119-136.

Roepstorff, T., Wiggens, S. (2011). New global realities governing agribusiness. UNIDO: Vienna.

Saith, A. (2001). From village artisans to industrial clusters: Agendas and policy gaps in Indian rural industry. Journal of Agrarian change 1(1), 81-123.

Saith, A. (2004). Social protection, decent work and development. International Institute for Labour Studies (IILS).

Scoones, I. (2009). Livelihoods perspectives and rural development. J. Peas. Stud., 36(1), 171-196.
Senadza, B. (2012). Non-farm income diversification in rural Ghana: Patterns and determinants. Afr. Dev. Rev., 24(3), 233-244.

Sunyani West District Assembly (2015). Annual composite budget 2015. Sunyani: SWDA.

Sunyani West District Assembly (2017). Annual Action Plan, 2017. Sunyani: SWDA.

Taruvinga, A., Gumpo, N., Mudemba, R., Ngarava, S. (2018). Rural income portfolios, compositions, diversity and determinants: Evidence from Nyandeni local municipality, South Africa. Int. J. Dev. Sust,. 7(2), 792-807.

Tasie, C.M., Offor, U., Wilcox, G. (2012). Determinants of off-farm income diversification in Rivers state, Nigeria. Wudp. J. Agric. Res., 1(8), 331-334.

Tobin, J.C. (2009). Hunger Efforts and Food Security. New York: Nova Science Publishers Inc.

Tuyen, T.Q. (2014). A review on the link between non-farm employment, land and rural livelihoods in developing countries and Vietnam. Ekonomskihorizonti, 16(2), 113.

Van de Berg, M., Kumbi, G.E. (2006). Poverty and the rural nonfarm economy in Oromia, Ethiopia. Agric. Econ., 35, 469-475.

Weatherspoon, D.D., Reardon, T. (2003). The rise of supermarkets in Africa: implications for agrifood systems and the rural poor. Dev. Polic. Rev., 21(3), 333-355.

Wiggins, S., Hazell, P. (2011). Access to rural non-farm employment and enterprise development. Background Paper for the IFAD Rural Poverty Report.

Winters, P., Essam, T., Zezza, A., Davis, B., Carletto, C. (2010). Patterns of rural development: A cross-country comparison using microeconomic data. J. Agric. Econ., 61(3), 628-651.

Zakaria, H., Abujaja, A.M., Adam, H., Salifu, W.Y. (2015). Does gender make any differences in livelihood diversification? Evidence from Northern Ghana. Int. J. Agric. Ext. Rural Dev. Stud., 1(1), 36-51. 
